\title{
Water temperature and benthic light levels drive horizontal expansion of Caulerpa taxifolia in native and invasive locations
}

\author{
Dana D. Burfeind ${ }^{1, *}$, Katherine R. O'Brien ${ }^{2}$, James W. Udy ${ }^{3}$ \\ ${ }^{1}$ School of Biological Sciences, and ${ }^{2}$ School of Chemical Engineering, University of Queensland, St Lucia, Queensland 4072, \\ Australia \\ ${ }^{3}$ Healthy Waterways, PO Box 13086, George Street, Brisbane, Queensland 4003, Australia
}

\begin{abstract}
Caulerpa taxifolia is a marine alga native to tropical and subtropical regions, and invasive in temperate regions worldwide. The aim of this study was to quantify the impacts of water temperature, benthic light and nutrient enrichment on horizontal expansion of $C$. taxifolia, in the absence of competition from other benthic flora. Field experiments were undertaken in 1 native C. taxifolia population (Moreton Bay, Australia) and 2 invasive C. taxifolia populations (Pittwater and Port River Estuary, Australia). Manipulative experiments were conducted across a range of seasons and different shading and nutrient treatments to determine the effects of water temperature, benthic light dose and nutrient enrichment on horizontal expansion (stolon extension rate). Nitrogen and phosphorus enrichment had negligible effects on stolon extension rate at all locations, suggesting that nutrient conditions at the study sites were saturating for C. taxifolia. Shading significantly reduced stolon extension in Pittwater, and season/water temperature significantly affected stolon extension in Port River Estuary; only in Moreton Bay were both shading and season/water temperature significant. When all data were pooled in a general linear model, water temperature and average daily benthic light dose (log-transformed) significantly affected stolon extension, but nutrient enrichment did not. Site, season and the interaction between water temperature and benthic light dose also improved model performance, indicating that site-specific factors which varied between seasons also affected the measured stolon extension. Overall, our results indicate that $C$. taxifolia growth increased with light disproportionately at higher temperatures.
\end{abstract}

KEY WORDS: Invasive species $\cdot$ Light manipulation $\cdot$ Nutrient enrichment

\section{INTRODUCTION}

Increasing coastal development is contributing to eutrophication and increased sediment loads in coastal systems worldwide (Rabalais et al. 2009). These changes in the light, temperature and nutrient climate in coastal waters can alter the suitability of nearshore habitats for the growth and survival of several marine organisms (Occhipinti-Ambrogi \& Savini 2003). The corresponding nutrient enrich- ment and reduced benthic light availability can promote the dominance of invasive macroalgae in coastal systems, due to the lower light requirements of macroalgae compared to seagrasses (Abal \& Dennison 1996, Burfeind \& Udy 2009) or corals (Fabricius 2005). Therefore, it is critical to understand the biology of invasive macroalgal species and the way environmental conditions influence established populations. The present study provides a direct test of how sensitive the expansion of an 
invader will be to changing estuarine environments.

The green alga Caulerpa taxifolia is an invasive species of international significance which has colonized a substantial area of the Mediterranean Sea (Meinesz \& Hesse 1991, Meinesz et al. 2001), southern California (Williams \& Grosholz 2002) and Japan (Komatsu et al. 2003). C. taxifolia has also colonized temperate locations in Australia, including 8 estuaries in New South Wales (Creese et al. 2004) and the Port River-Barker Inlet system in South Australia (Cheshire et al. 2002). C. taxifolia was likely introduced to temperate Australia through the aquarium trade and subsequently transported to other estuaries by humans (e.g. fragments attached to boat anchors, Creese et al. 2004). Australia is unique in that native and invasive populations of $C$. taxifolia occur within $600 \mathrm{~km}$ of each other along the east coast. In Moreton Bay, Australia, where it is native, C. taxifolia distribution is expanding (Burfeind \& Udy 2009). In the case of Moreton Bay, seagrass has been lost due to declining water quality (increased nutrients, decreased benthic light availability), creating unvegetated areas for C. taxifolia to opportunistically colonize (N. Udy unpubl. data, Burfeind \& Udy 2009).

As with other marine algae, Caulerpa taxifolia growth and distribution is closely tied to environmental drivers (light, temperature, nutrients). C. taxifolia has been shown to flourish in marginal and nutrient-stressed communities (Chisholm et al. 1997) due to its low light requirement and ability to uptake nutrients from both the sediment and water column (Williams 1984, Chisholm et al. 1996). High sediment nutrient concentrations increase $C$. taxifolia growth and biomass (Ceccherelli \& Cinelli 1997, Burfeind \& Udy 2009) and stimulate C. taxifolia growth in beds mixed with seagrass (Ceccherelli \& Sechi 2002). Water temperature also plays a key role in regulating seasonal changes in $C$. taxifolia biomass (Thibaut et al. 2004) and large-scale changes (loss) in distribution (Komatsu et al. 2003, Iveša et al. 2006).

Caulerpa taxifolia can rapidly expand and become dominant once it has been introduced. In the case of the Mediterranean (invasive), C. taxifolia was first found in a $1 \mathrm{~m}^{2}$ patch off the coast of Monaco in 1984 and expanded to cover over 131000 ha by 2000 (Meinesz et al. 2001). In Moreton Bay (native), $10 \%$ of 143 sites surveyed in 1998 had C. taxifolia present, yet when the same sites were resurveyed in 2005, C. taxifolia was observed at $28 \%$ of sites (Burfeind \& Udy 2009). Even though there has been substantial effort placed on mapping the expansion of C. taxifolia in locations where it is invasive (e.g. Meinesz et al.
2001, Creese et al. 2004), there have been few process or modelling studies (e.g. Hill et al. 1998, Ruesink \& Collado-Vides 2006) that attempt to quantify the potential expansion rate of $C$. taxifolia beds in response to environmental variables.

The objectives of the current study were to measure Caulerpa taxifolia expansion rates and assess the impact of environmental drivers (light, temperature and nutrients) on expansion rates in native and invasive locations. In particular, this study aimed to determine general relationships between $C$. taxifolia expansion rates and environmental drivers, which would be valid across different sites and regions.

\section{MATERIALS AND METHODS}

The impact of nutrient enrichment and shading on Caulerpa taxifolia stolon extension was assessed using manipulative field experiments at 3 sites around Australia. C. taxifolia is native at 1 of the sites and invasive at the other 2 sites. Experiments were conducted in 4 seasons at the site where $C$. taxifolia is native, and 2 seasons at each of the sites where C. taxifolia is invasive.

\section{Study sites}

One Mile Harbour, Moreton Bay, Queensland

Moreton Bay is located in southeast Queensland, Australia (Fig. 1), and contains the southernmost extent of native Caulerpa taxifolia on the east coast of Australia. C. taxifolia has been recorded in Moreton Bay since 1946 (Phillips \& Price 2002), but its extent has increased in recent years, as it has colonized unvegetated benthic habitat created by seagrass loss due to reduced water quality in the bay (Thomas 2003, Burfeind \& Udy 2009).

The bay is bordered on the west by the mainland and on the eastern side by 3 large islands (Moreton, North Stradbroke and South Stradbroke) creating a wedge-shaped bay. Moreton Bay is $100 \mathrm{~km}$ long, ranging from $31 \mathrm{~km}$ wide at the northernmost point to $1 \mathrm{~km}$ wide at the southernmost part of the bay, with a tidal range of 1 to $2 \mathrm{~m}$ (Abal \& Dennison 1996). Our study took place at One Mile Harbour adjacent to Dunwich on North Stradbroke Island. Mixed seagrass beds covered shallow intertidal areas to ca. $0.5 \mathrm{~m}$, and subtidal areas $(0.5$ to $3 \mathrm{~m}$ depth) were covered by a monotypic stand of Caulerpa taxifolia. 


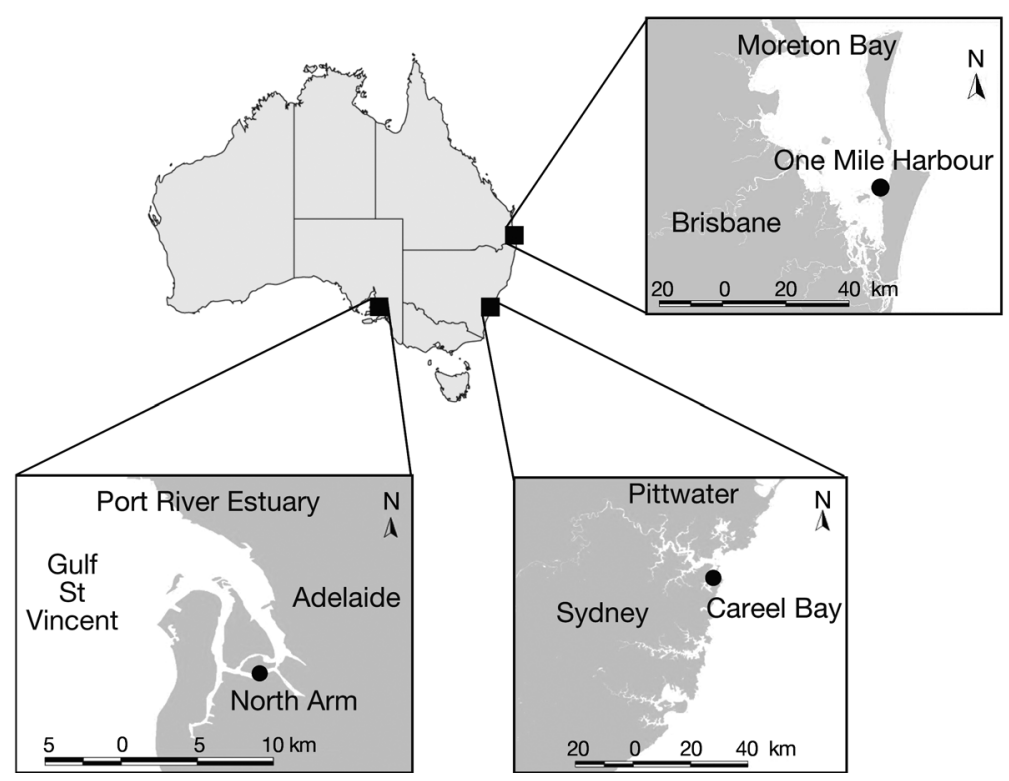

Fig. 1. Location of study sites within Moreton Bay, Queensland; Pittwater, New South Wales; and Port River Estuary, South Australia
The estuary has 2 connections to Gulf St Vincent (the Port River and Barker Inlet) and semi-diurnal tides with a maximum amplitude of $2 \mathrm{~m}$ (Jones et al. 1996). It is heavily impacted through waste water discharge, industry and thermal pollution from a power plant located on Torrens Island. The power station discharges $3.9 \mathrm{Gl}$ of heated effluent per day (Thomas et al. 1986), adjacent to the study site at the North Arm Bridge on Torrens Island. The water temperature at this site (13 to $34^{\circ} \mathrm{C}$, Jones et al. 1996) can be up to $12^{\circ} \mathrm{C}$ higher than the temperature in Gulf St Vincent (ca. 12 to $22^{\circ} \mathrm{C}$, de Silva Samarasinghe et al. 2003). Caulerpa taxifolia has colonized the substrate from the low tide level to a depth of at least $3 \mathrm{~m}$ with a continuous bed of $C$. taxifolia and sparse patches of C. racemosa (also introduced).

\section{Experimental design}

Pittwater Estuary is approximately $25 \mathrm{~km}$ north of Sydney in New South Wales (Fig. 1). Caulerpa taxifolia was first identified in Pittwater within Careel Bay in December 2000, covering ca. 52 ha of benthic area as of 2004 (Creese et al. 2004).

Pittwater Estuary is shallow (average depth $<5 \mathrm{~m}$ ) with a mean tidal range of $1.8 \mathrm{~m}$. It is a branch of the Hawkesbury River; however, it receives minimal freshwater input and has a direct connection to the ocean so there is little variation in salinity (30 to 35 ppt, Bell et al. 1988). Our study took place in Careel Bay where the intertidal zone to ca. $0.5 \mathrm{~m}$ is covered with Zostera muelleri (= Zostera capricornii) and areas greater than 0.5 to ca. $4 \mathrm{~m}$ are covered with a monotypic bed of Caulerpa taxifolia.

\section{North Arm, Port River Estuary, South Australia}

The Port River Estuary is a shallow (5 to $15 \mathrm{~m}$ depth) urban waterway in Adelaide, South Australia (Fig. 1). Caulerpa taxifolia is not native to South Australia; it was discovered in the Port River in 2002 (Cheshire et al. 2002) and continues to spread through the estuary (Collings et al. 2004). To date there are no confirmed introductions of $C$. taxifolia in South Australia outside the Port River Estuary.
Experiments were conducted over 12 d at 3 locations, over a range of seasons (Table 1). While the temporal resolution of sampling was insufficient to characterize the seasonality of the measurements, for simplicity, we will refer to sampling events by their season when discussing results. The initial experimental design included sampling 4 seasons in both Moreton Bay and Pittwater; however, a bloom of filamentous algae at Pittwater in late August 2007 covered the Caulerpa taxifolia bed and reduced $C$. taxifolia cover at that site to less than $10 \%$. As of March 2008, the C. taxifolia bed had not recovered; hence only 2 seasons could be sampled at that location. Logistical constraints restricted sampling at the Port River to 2 seasons; summer and winter were chosen to capture maximum potential differences in environmental conditions.

Experimental plots were haphazardly created along a transect in a continuous bed of Caulerpa taxifolia ca. $50 \mathrm{~cm}$ below low tide water level. Plots were created by placing a $30 \mathrm{~cm}$ diameter plastic ring into the sediment. All C. taxifolia for $45 \mathrm{~cm}$ surrounding the ring was removed by hand (as per Street 2007) and there was at least $1 \mathrm{~m}$ between plots. The vegetation removal created a 'bull's eye' where there was a continuous patch of $C$. taxifolia surrounded by unvegetated substrate (Fig. 2a). This patch was used 
Table 1. Summary of dates of experiments in corresponding season and location, and associated water temperature, clarity (light attenuation coefficient, $K_{d}$ ) and light (photosynthetically active radiation, PAR) data

\begin{tabular}{|c|c|c|c|c|c|c|c|c|}
\hline Location & Expt start & Season & $\begin{array}{c}\text { Water } \\
\text { temp }\left({ }^{\circ} \mathrm{C}\right)\end{array}$ & $\begin{array}{c}K_{d} \\
\left(\mathrm{~m}^{-1}\right)\end{array}$ & $\begin{array}{l}\text { Avg. daily surface } \\
\text { PAR dose (mol } \\
\left.\text { quanta } \mathrm{m}^{-2} \mathrm{~d}^{-1}\right)\end{array}$ & $\begin{array}{c}\text { Sunrise } \\
\text { time }\end{array}$ & $\begin{array}{c}\text { Sunset } \\
\text { time }\end{array}$ & $\begin{array}{l}\text { Avg. daily benthic } \\
\text { PAR dose (mol } \\
\left.\text { quanta } \mathrm{m}^{-2} \mathrm{~d}^{-1}\right)\end{array}$ \\
\hline \multirow[t]{4}{*}{ Moreton Bay } & 11 Feb 07 & Summer & 29 & 1 & 38.7 & $05: 31$ & $18: 31$ & 17 \\
\hline & 7 May 07 & Fall & 22 & 0.44 & 25.3 & $06: 18$ & $17: 09$ & 26 \\
\hline & 16 Aug 07 & Winter & 20 & 0.28 & 23.5 & $06: 34$ & $17: 14$ & 22 \\
\hline & 17 Nov 07 & Spring & 24 & 0.55 & 46.2 & $04: 46$ & $18: 20$ & 37 \\
\hline \multirow[t]{2}{*}{ Pittwater } & 14 Mar 07 & Fall & 22 & 0.18 & 27.3 & $05: 46$ & $18: 08$ & 32 \\
\hline & 26 May 07 & Winter & 19 & 0.24 & 19.1 & $06: 51$ & $16: 55$ & 24 \\
\hline \multirow[t]{2}{*}{ Port River Estuary } & $25 \mathrm{Jul} 07$ & Winter & 15 & 0.2 & 20.3 & $07: 24$ & $17: 14$ & 17 \\
\hline & 29 Jan 08 & Summer & 26 & 0.44 & 43.1 & $06: 37$ & $20: 21$ & 51 \\
\hline
\end{tabular}

a
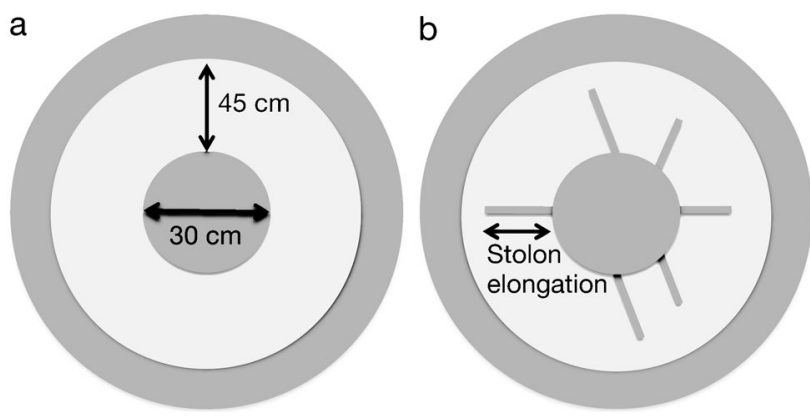

Fig. 2. Graphical representation of (a) experimental plots created for manipulative experiments and (b) measurement of stolon length within experimental plots. Darker areas represent Caulerpa taxifolia beds and lighter areas represent unvegetated substrate

to represent a C. taxifolia bed that was expanding without competition from other benthic vegetation; therefore, this measure represents the maximum expected stolon extension rate for the system. Treatments were then applied to these experimental patches. Stolon extension (new growth) was measured as the sum of the length of individual stolons protruding from circle perimeter into the unvegetated area on Day $12\left(S E_{\text {total }}\right)$, and used to calculate mean extension per stolon $\left(S E_{\text {mean }}\right)$, as shown in (Fig. 2b).

\section{Light reduction experiment}

For each benthic light reduction experiment, 6 replicate plots were created of 5 treatments: 10, 50, 80, 90 and $100 \%$ (control) of benthic light availability. We did not include a procedural control in our experimental design (i.e. metal frame with transpar- ent material), as it is likely that any transparent material we used would have collected epiphytes and changed hydrodynamics more than the shade cloth, therefore would not have been a true control. Hence, it was not possible to simulate the hydrodynamic impact of the shade cloth without shading. Metal frame domes $75 \mathrm{~cm}$ in diameter and $40 \mathrm{~cm}$ in height covered with different thicknesses of shade cloth were used to reduce light in experimental plots (Burfeind \& Udy 2009). Shade cloth was cleaned every $3 \mathrm{~d}$.

\section{Nutrient enrichment experiment}

Nutrient enrichment experiments were conducted concurrent to the light reduction experiments (sharing a common control). Control plots were created with the same method as experimental plots and did not have a treatment added. For each experiment, 6 replicate plots of 4 treatments (randomized block design) were created: control, nitrogen addition, phosphorus addition, and nitrogen $(\mathrm{N})+$ phosphorus $(\mathrm{P})$ addition. Nutrients were added to sites by filling 6 plastic $10 \mathrm{ml}$ tubes (with holes to allow water exchange) with nutrients and placing them into the sediment within the Caulerpa taxifolia patch. In each tube $3 \mathrm{~g} \mathrm{~N}$ as $46 \%$ urea $\left(\mathrm{NH}_{2}\right)_{2} \mathrm{CO}$ (Brunnings) and/or $1 \mathrm{~g} \mathrm{P}$ as $9.1 \% \mathrm{PO}_{4}$ (Richgrow Garden Products) was added for $\mathrm{N}$ and $\mathrm{P}$ enrichment experiments. Nutrient tubes were replaced every 3 d. Udy \& Dennison (1997) found that sediment nutrient enrichment has a localized effect on the location where it is applied; therefore, we are confident that there was no contamination from nutrient enrichment in adjacent plots. 


\section{Water temperature and benthic light dose}

Water temperature and benthic light dose varied both seasonally and between sites. Surface water temperature was measured using a mercury thermometer at midday. In preliminary studies, we found less than 1 degree of variation between days, therefore only a single measurement of water temperature was taken during each experiment.

The average daily benthic light dose $\bar{I}_{\text {daily }}$ (mol quanta $\mathrm{m}^{-2} \mathrm{~d}^{-1}$ ) for each experiment was calculated from half-hourly benthic light $I_{\text {benthic }}$ (mol quanta $\mathrm{m}^{-2}$ $\mathrm{s}^{-1}$ ), which was determined from surface light $I_{\text {surface }}$ (mol quanta $\mathrm{m}^{-2} \mathrm{~s}^{-1}$ ), water depth $z(\mathrm{~m})$ and light attenuation coefficient $K_{d}\left(\mathrm{~m}^{-1}\right)$, with the appropriate unit conversions for time $(t)$ :

$$
\bar{I}_{\text {daily }}=\frac{1}{12} \int_{0}^{12} I_{\text {benthic }}(t) \mathrm{d} t=\frac{1}{12} \int_{0}^{12} I_{\text {surface }}(t) \mathrm{e}^{-K_{d} z(t)} \mathrm{d} t
$$

The half-hourly time-step was used in Eq. (1) to capture the effect on benthic light of the interaction between daily tidal and light cycles during each experiment. Eq. (1) did not account for shading due to benthic vegetation, and so was an estimate of the light available for Caulerpa taxifolia expansion on unvegetated substrate.

Water depth in Eq. (1) was calculated from daily tidal heights at primary ports adjacent to study sites: Brisbane Bar, Sydney Harbour and Port Adelaide (Australian Hydrographic Service), corrected using offset for locations in Moreton Bay and Pittwater. Half-hourly tidal height was interpolated from high and low tide times and depths using a cubic spline. Water depth $z(\mathrm{~m})$ was determined over the course of each experiment by adding the low tide depth at each site to the half-hourly interpolated tidal depth.

At the Pittwater site, light attenuation for Eq. (1) was determined from light measured at the surface and at $1 \mathrm{~m}$ (using a Li-cor, LI-192 underwater quantum sensor) using the following equation:

$$
K_{d}=\left[\ln \left(I_{\text {surface }} / I_{\text {benthic }}\right)\right] / z
$$

Light attenuation coefficients were calculated at Moreton Bay and Port River sites from Secchi depth monitoring data, due to malfunction and flooding of light loggers deployed at those sites. Secchi depths in Moreton Bay were collected as part of the Queensland Environmental Protection Agency (EPA) Ecosystem Health Monitoring Program (EHMP 2006). The EPA conducts monthly monitoring of water quality across Moreton Bay, and we selected a benthic study site adjacent to a monitoring location (\#502).
Collection methods are detailed in the EHMP (2006) technical report. We used monitoring data from the South Australian EPA (Site 4) for light attenuation data for the Port River. $K_{d}$ was calculated from Secchi depth $\left(Z_{\mathrm{SD}}\right)$ using the following equation (Poole \& Atkins 1929):

$$
K_{d}=1.7 / Z_{\mathrm{SD}}
$$

Half-hourly incident light in Eq. (1) was determined from maximum daily light assuming light varied between sunset and sunrise according to a sine-cubed function, where maximum daily incident light was determined from the total daily light dose by multiplying by $\pi$, and dividing by the photoperiod (i.e. difference between sunrise and sunset) as per Chapra (1997). Sunrise and sunset times were determined from Geosciences Australia (www.ga. gov.au/geodesy/astro/sunrise.jsp). Total daily light dose of photosynthetically active radiation was determined from Global Solar Energy, provided by the Bureau of Meteorology. Site 040842 (Brisbane Airport, Queensland) was used for Moreton Bay; Site 066037 (Sydney Airport AMO, New South Wales) for Pittwater and Site 023090 (Adelaide Kent Town, South Australia) for Port River. Global solar Energy ( $\mathrm{MJ} \mathrm{m}^{-2}$ ) was converted to total daily incident light dose (photosynthetically active radiation mol quanta $\mathrm{m}^{-2} \mathrm{~d}^{-1}$ ) using $0.5639 \mathrm{MJ} \mathrm{mol}^{-1}$ quanta (see Grinham 2007).

\section{Analysis}

All statistical analyses were conducted in $\mathrm{R}$. ANOVA analysis was conducted at each site for both nutrient enrichment and shading experiments $(\alpha=$ 0.05). Tukey's post hoc test $(\alpha=0.05)$ was used for pairwise comparison of means (Day \& Quinn 1989) where significant differences where indicated by ANOVA. Analyses were undertaken for both $S E_{\text {total }}$ and $S E_{\text {mean. }}$ Visual assessment of model residuals found that assumptions of normality and homogeneity of variance were not met for $S E_{\text {mean }}$ (even under log transformation) and therefore it was not used as the model response. However total stolon extension did satisfy these conditions when transformed as $\log \left(S E_{\text {total }}+1\right)$. Hence total stolon extension was used as the response in all analyses.

All predictors were continuous except for Site, Season, $\mathrm{N}$ enrichment and $\mathrm{P}$ enrichment, which were treated as categorical variables. Investigation of the shape of response identified non-linear responses for benthic light dose, which was modelled as $\log \left(\bar{I}_{\text {daily }}\right)$. 
Deviation of water temperature from $20^{\circ} \mathrm{C}$ was used as a predictor variable in all analyses, because temperature deviation can be expressed in units of either Celsius or Kelvin. This format is common in hydrobiological modelling and has no effect on the analysis.

Differences in $S E_{\text {total }}$ in the nutrient enrichment experiments were compared at each site with a 3way ANOVA with sampling event (Season), N enrichment and $\mathrm{P}$ enrichment as categorical variables. Two-way ANOVAs were conducted for the shading experiments at each site, with sampling event (Season) as a categorical factor and shading treatment (Treatment) as a continuous factor. The same analysis was then repeated with water temperature (Temperature) and $\log \left(\bar{I}_{\text {daily }}\right)$ as continuous factors.

Data were then pooled across all sites and analyzed using a general linear modelling approach to determine whether stolon extension was affected by a suite of environmental variables, including site, season, benthic light dose, water temperature and nutrient enrichment. The significance of predictors was assessed using backwards elimination of terms based on Akaike's information criterion (AIC).

Table 2. Results from 3-way ANOVA on stolon extension $\left(S E_{\text {total }}\right)$ in the nutrient enrichment experiment. Data were $\log (x+1)$ transformed to reduce heteroscadicity. Significant values in bold

\begin{tabular}{|lrrrr|}
\hline & df & \multicolumn{1}{c}{ MS } & $F$ & p-value \\
\hline Moreton Bay & & & & \\
Season & 3 & 30.704 & 92.973 & $<\mathbf{0 . 0 0 1}$ \\
$\mathrm{N}$ & 1 & 0.387 & 1.171 & 0.282 \\
$\mathrm{P}$ & 1 & 0.001 & 0.002 & 0.968 \\
$\mathrm{~N} \times \mathrm{P}$ & 1 & 0.431 & 1.3047 & 0.257 \\
Season $\times \mathrm{N}$ & 1 & 0.509 & 1.54 & 0.211 \\
Season $\times \mathrm{P}$ & 1 & 0.328 & 0.9925 & 0.401 \\
Residuals & 83 & 0.33 & & \\
Pittwater & & & & \\
Season & 1 & 0.931 & 2.04 & 0.161 \\
$\mathrm{~N}$ & 1 & 0.039 & 0.087 & 0.769 \\
$\mathrm{P}$ & 1 & 0.047 & 0.104 & 0.749 \\
$\mathrm{~N} \times \mathrm{P}$ & 1 & 0.251 & 0.549 & 0.463 \\
Season $\times \mathrm{N}$ & 1 & 0.0118 & 0.258 & 0.614 \\
Season $\times \mathrm{P}$ & 1 & 0.638 & 1.39 & 0.244 \\
Residuals & 41 & 0.457 & & \\
Port River & & & & \\
Season & 1 & 166.246 & 1009.139 & $<\mathbf{0 . 0 0 1}$ \\
$\mathrm{N}$ & 1 & 0.449 & 2.724 & 0.107 \\
$\mathrm{P}$ & 1 & 1.183 & 7.181 & $\mathbf{0 . 0 1 1}$ \\
$\mathrm{N} \times \mathrm{P}$ & 1 & 0.087 & 0.529 & $\mathbf{0 . 0 4 7}$ \\
Season $\times \mathrm{N}$ & 1 & 0.159 & 0.964 & 0.332 \\
Season $\times \mathrm{P}$ & 1 & 0.299 & 1.87 & 0.185 \\
Residuals & 41 & 0.165 & & \\
\hline & & & & \\
\hline
\end{tabular}
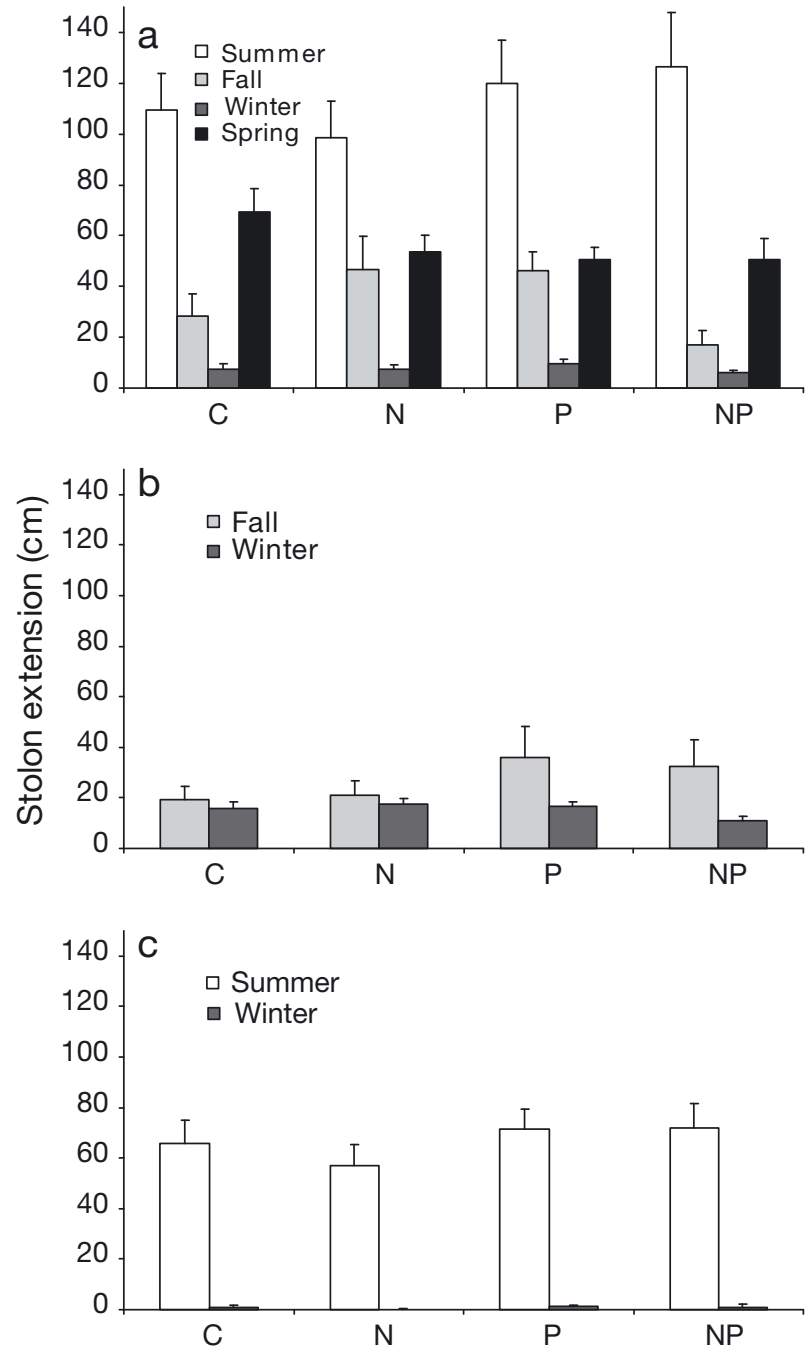

Fig. 3. Caulerpa taxifolia. Mean stolon extension $\left(S E_{\text {total }}\right)$ after $12 \mathrm{~d}( \pm \mathrm{SE})$ from the nutrient enrichment experiment in different seasons in (a) Moreton Bay, (b) Pittwater and (c) Port River Estuary

\section{RESULTS}

$\mathrm{N}$ enrichment did not significantly affect total stolon extension $S E_{\text {total }}$ at any of the sites, either alone or interacting with $\mathrm{P}$ enrichment (Table 2, Fig. 3). $\mathrm{P}$ enrichment had a significant affect only at Port River (Table 2); however, the effect was so small as to be considered negligible $(0.07$ to $0.7 \mathrm{~cm}$ increase in $S E_{\text {total }}$ due to P enrichment compared to 31 to $51 \mathrm{~cm}$ difference between summer and winter). Season had a significant but small effect on stolon extension in Moreton Bay: compared to the fall season, total stolon extension was 0.3 to $2 \mathrm{~cm}$ higher in summer/spring and 1 to $4 \mathrm{~cm}$ lower in winter. Neither 
Table 3. Results from 2-way ANOVA on stolon extension $\left(S E_{\text {total }}\right)$ in the manipulative light experiment, with Season as categorical factor and \% shade (Treatment) as continuous factor. Data were $\log (x+1)$ transformed to reduce heteroscadicity. Significant values in bold

\begin{tabular}{|lrccr|}
\hline & df & MS & $F$ & p-value \\
\hline Moreton Bay & & & & \\
Season & 3 & 27.244 & 79.72 & $<\mathbf{0 . 0 0 1}$ \\
Treatment & 1 & 43.015 & 125.862 & $<\mathbf{0 . 0 0 1}$ \\
Season $\times$ Treatment & 3 & 3.97 & 11.605 & $\mathbf{< 0 . 0 0 1}$ \\
Residuals & 128 & 0.342 & & \\
Pittwater & & & & \\
Season & 1 & 1.221 & 3.255 & 0.077 \\
Treatment & 1 & 3.251 & 8.664 & $<\mathbf{0 . 0 0 1}$ \\
Season $\times$ Treatment & 1 & 0.3849 & 1.026 & 0.315 \\
Residuals & 56 & & & \\
Port River & & & & \\
Season & 1 & 183 & 521.357 & $\mathbf{< 0 . 0 0 1}$ \\
Treatment & 1 & 0.028 & 0.0793 & 0.779 \\
Season $\times$ Treatment & 1 & 0.021 & 0.0601 & 0.807 \\
Residuals & 56 & 0.352 & & \\
\hline
\end{tabular}

Season nor N/P enrichment significantly affected stolon extension at Pittwater, where the field experiments captured only a minimum seasonal range. When the data from all nutrient enrichment experiments and controls were pooled across all sites, neither N, P or interaction between $\mathrm{N}$ and P significantly improved model performance as indicated by AIC.

Shading had a significant effect on Caulerpa taxifolia expansion, but this affect varied between sites and season. Season, shading treatment and the interaction between these factors all had a highly significant effect on stolon extension in Moreton Bay (Table 3, Fig. 4). In Pittwater, where seasonal variation was lowest, shading significantly reduced total stolon extension, but Season did not have a significant effect. In Port River Estuary, Season significantly affected total stolon extension but shading did not. These effects could be largely described by water temperature and benthic light dose; when the ANOVAs were rerun using water temperature instead of Season and $\log \left(\bar{I}_{\text {daily }}\right)$ instead of Treatment, Temperature and light were significant at Port River but with no interactions, benthic light alone was significant at Pittwater, and both factors and their interactions were significant at Moreton Bay (Tables $3 \& 4$ ).

Site, season, water temperature, $\log \left(\bar{I}_{\text {daily }}\right)$ and the interaction between light and water temperature were all found to significantly affect stolon extension when data from the shading treatments and controls
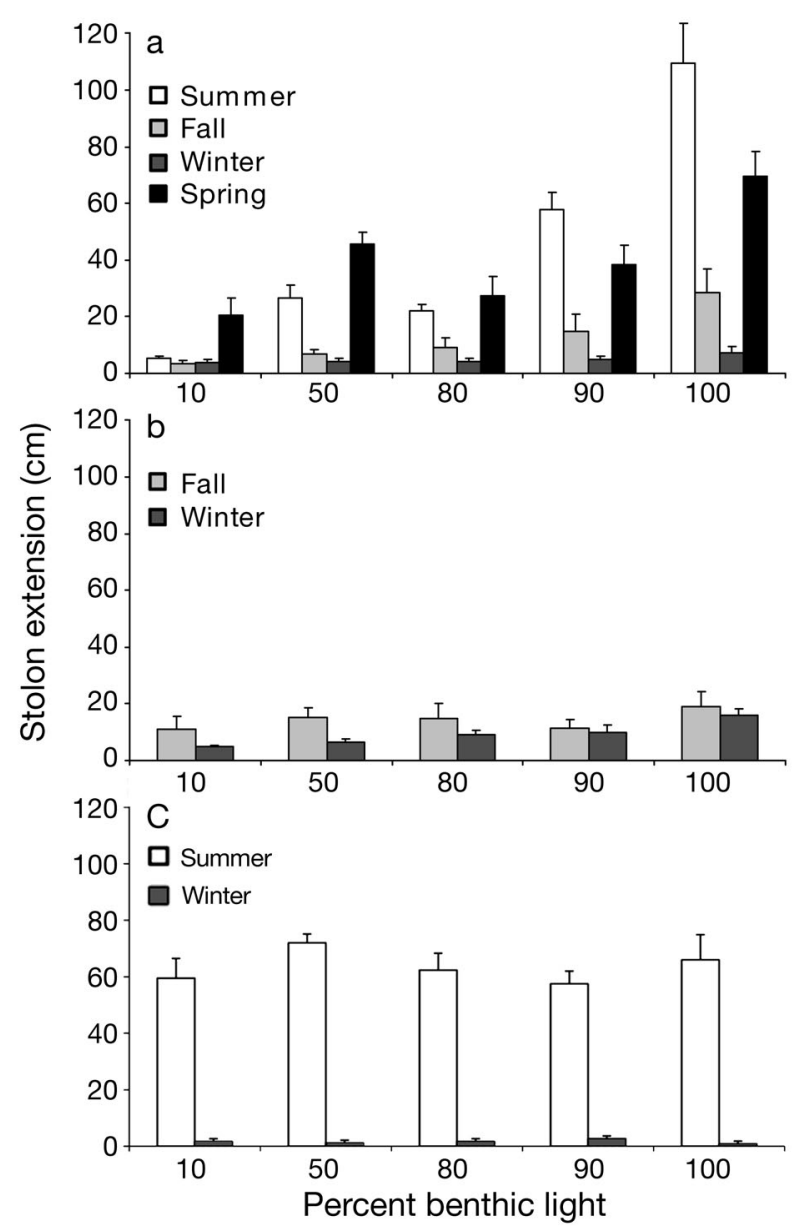

Fig. 4. Caulerpa taxifolia. Mean stolon extension $\left(S E_{\text {total }}\right)$ after $12 \mathrm{~d}( \pm \mathrm{SE})$ from the light reduction experiment in different seasons in (a) Moreton Bay, (b) Pittwater and (c) Port River Estuary

were analyzed across all sites and seasons. The general linear model including all of these factors as explanatory variables and fitted to data from all shading experiments and controls, pooled across all sites, explained $76 \%$ of the observed variation (Tables 5 \& 6).

The relative importance of individual variables in assessing model performance was assessed by backwards elimination: each variable in turn was eliminated from the model and performance was assessed using AIC. A smaller value of AIC indicates better model performance. Removing any 1 of the 4 variables or the light-temperature interaction reduced model performance, indicating that including all of these variables produced the best fit to the measured stolon extension (Table 5).

This indicates that there were processes affecting the rate of Caulerpa taxifolia expansion which were specific to different sites and seasons, and 
Table 4. Results from 2-way ANOVA on stolon extension $\left(S E_{\text {total }}\right)$ in the manipulative light experiment, with water temperature and $\log \left(\right.$ benthic light dose) $\left(\log \left(\bar{I}_{\text {daily }}\right)\right)$ as continuous factors. Data were $\log (x+1)$ transformed to reduce heteroscadicity. Significant values in bold

\begin{tabular}{|lrrr|}
\hline & df & \multicolumn{1}{c|}{$F$} & p-value \\
\hline Moreton Bay & & & \\
$\log \left(\bar{I}_{\text {daily }}\right)$ & 134 & 79.01 & $<\mathbf{0 . 0 0 1}$ \\
$\Delta$ Temperature & 133 & 136.71 & $<\mathbf{0 . 0 0 1}$ \\
$\log \left(\bar{I}_{\text {daily }}\right) \times \Delta$ Temperature & 132 & 9.76 & $\mathbf{0 . 0 0 2}$ \\
Pittwater & & & \\
Log $\left(\bar{I}_{\text {daily }}\right)$ & 58 & 9.71 & $\mathbf{0 . 0 0 3}$ \\
$\Delta$ Temperature & 57 & 1.31 & 0.258 \\
Log $\left(\bar{I}_{\text {daily }}\right) \times \Delta$ Temperature & 56 & 0.391 & 0.535 \\
Port River & & & \\
$\log \left(\bar{I}_{\text {daily }}\right)$ & 58 & 64.59 & $<\mathbf{0 . 0 0 1}$ \\
$\Delta$ Temperature & 57 & 146.34 & $<\mathbf{0 . 0 0 1}$ \\
$\log \left(\bar{I}_{\text {daily }}\right) \times \Delta$ Temperature & 56 & 0.134 & 0.715 \\
\hline
\end{tabular}

Table 5. Impact of removing individual variables on ability of linear model to predict $\log ($ stolon extension +1 ), where model performance is measured by Akaike's information criterion (AIC, lower AIC indicates better performance) and coefficient of regression $\mathrm{R}^{2}$

\begin{tabular}{|lcc|}
\hline Explanatory variables eliminated & AIC & Adjusted $\mathrm{R}^{2}$ \\
\hline None & 510 & 0.76 \\
Season & 546 & 0.71 \\
Site & 549 & 0.71 \\
Site and Season & 560 & 0.69 \\
Light $\times$ Temperature & 535 & 0.73 \\
Temperature $\left(T-20^{\circ} \mathrm{C}\right)$ & 559 & 0.71 \\
$\log \left(\bar{I}_{\text {daily }}\right)$ & 595 & 0.66 \\
\hline
\end{tabular}

Table 6. Coefficients, with standard deviation and significance, for general linear model of stolon extension across all sites and seasons for shading experiments. Null deviance: 421 on 255 degrees of freedom; Residual deviance: 128 on 252 degrees of freedom, AIC: 560. Significant values in bold

\begin{tabular}{|lcccr|}
\hline & Estimate & $\mathrm{SE}$ & $t$-value & $\mathrm{p}$-value \\
\hline Intercept & 1.124 & 0.157 & 7.168 & $\mathbf{< 0 . 0 0 1}$ \\
$\Delta$ Temperature & 0.047 & 0.029 & 1.641 & 0.102 \\
Log $(I)$ & 0.331 & 0.059 & 5.541 & $<\mathbf{0 . 0 0 1}$ \\
$\Delta$ Temperature & 0.068 & 0.012 & 5.904 & $\mathbf{< 0 . 0 0 1}$ \\
$\times \log \left(\bar{I}_{\text {daily }}\right)$ & & & & \\
\hline
\end{tabular}

not captured by the light or temperature variables. Benthic light was the single most important factor affecting the performance of the general linear model (Table 5). While incorporating Site and Sea- son improved the model performance, removing both of these factors had a similar effect on model performance to removing water temperature (Table 5). This provides strong evidence that $C$. taxifolia expansion in these experiments was driven by benthic light dose and water temperature, with only minor site- and season-specific effects. On this basis, the experimental data can be used to generate a general model for the impact of light and temperature on C. taxifolia expansion. Removing the factors Site and Season from the general linear model yields the following equation, after transformation:

$$
S E_{\text {total }}=\mathrm{e}^{A} \bar{I}_{\text {daily }}{ }^{B+C\left(T-20^{\circ} \mathrm{C}\right)}-1
$$

where $S E_{\text {total }}$ is the total stolon extension $(\mathrm{cm})$ measured over the $12 \mathrm{~d}$ experiments under benthic light dose $\left(\bar{I}_{\text {daily }}\right)$, water temperature $T\left({ }^{\circ} \mathrm{C}\right)$, and $A=1.12$ $(\mathrm{SE} \pm 0.157), B=0.33(\mathrm{SE} \pm 0.06), C=0.068$ (SE \pm 0.011 ). Water temperature was only significant in the interaction with daily benthic light dose. This is because water temperature was the same for each of the 5 light treatments in the 8 sampling events.

Benthic light dose and water temperature account for most of the variation in the data (Table 5), and the standard error in each coefficient is less than $20 \%$. Hence, while Eq. (4) does not include all site- and season-specific effects, it provides a useful tool for visualizing the overall impact of benthic light and water temperature on horizontal expansion of Caulerpa taxifolia. Re-arrangement of Eq. (4) enables calculation of the minimum benthic light dose required for total stolon extension over $12 \mathrm{~d}$ to exceed a threshold value $S E_{\mathrm{c}}$ in water temperature $T$ :

$$
\log \left(\bar{I}_{\text {daily }}\right)=\frac{\log \left(S E_{C}+1\right)-A}{B+C\left(T-20^{\circ} \mathrm{C}\right)}
$$

Caulerpa taxifolia can be limited by either water temperature or benthic light dose (Fig. 5). Each line in Fig. 5 corresponds to the minimum water temperature and light conditions required for stolon extension rate over $12 \mathrm{~d}$ to exceed the specified value, $S E_{\mathrm{c}}$. Stolon extension rate would be expected to be higher than the specified $S E_{\mathrm{c}}$ for temperature-light conditions above the line and lower than $S E_{\mathrm{c}}$ below the line generated by Eq. (5). The temperature andlight conditions associated with stolon extension rates measured in the control treatments are plotted on Fig. 5 for comparison with the model predictions.

As predicted by Eqs. (4) \& (5), Caulerpa taxifolia stolon extension rate in the control experiments was 


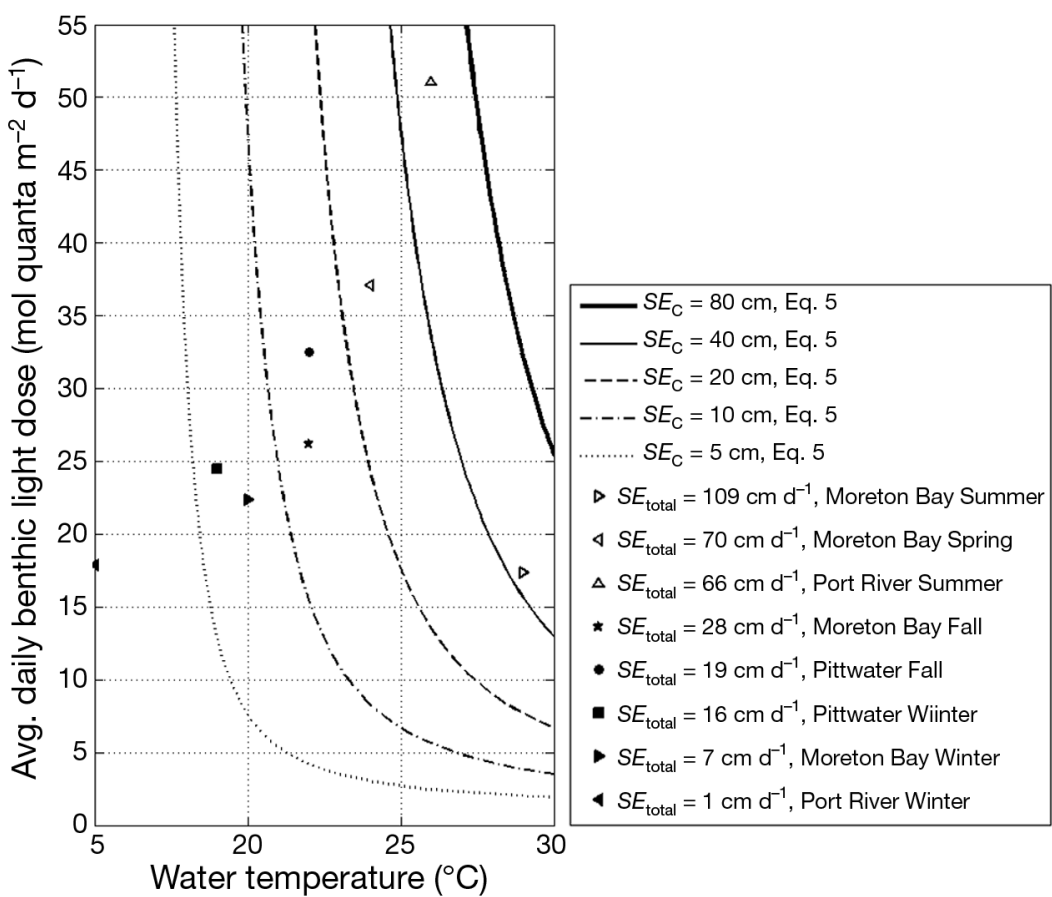

Fig. 5. Caulerpa taxifolia. Predicted water temperature and daily benthic light dose thresholds corresponding to stolon extension exceeding 5, 10, 20, 40 and $80 \mathrm{~cm}$ over $12 \mathrm{~d}$, calculated from Eq. (5). Measured values of $S E_{\text {total }}$ for control treatments are plotted at the water temperature and average daily benthic light dose under which they were measured. There was a strong correspondence between water temperature and benthic light dose during the field experiments, mediated by site- and season-specific factors demonstrated clearly in Fig 5: while there is some variation between sites and seasons, C. taxifolia stolon extension increases moving from the bottom left corner towards the top right, i.e. with increasing water temperature and benthic light dose. It is difficult to decouple the effects of benthic light and water temperature on $C$. taxifolia stolon extension rate, for a number of reasons. Water temperature and benthic light co-vary with seasonal changes in incident radiation. However benthic light dose is also affected by water clarity, which will vary with seasonal wind patterns, turbidity pulses and changes in chlorophyll concentrations. For example, the lowest benthic light doses during field experiments occurred in Moreton Bay in summer, under very high incident light, and in Port River Estuary in winter, under much lower incident light. Hence the site- and season-specific factors identified in the statistical model as affecting $C$. taxifolia stolon extension may be related to seasonal changes in water clarity which differ between site, and affect the interaction lowest under low temperature and light (bottom left corner of Fig. 5), and increased as light availability and water temperature increased towards the top right corner. Fig. 5 enables the total stolon extension measured over $12 \mathrm{~d}$ in the control treatments to be compared with $S E_{\text {total }}$ predicted from Eq. (5) based on the water temperature and benthic light dose. There was fair agreement between predicted temperature-light thresholds and measured data. Mean $S E_{\text {total }}$ for 5 of the 8 control treatments fell in the light-temperature region predicted from Eq. (5). Of the 3 control treatments which did not meet this criteria, each occurred under lower light-temperature conditions than predicted by Eq. (5), but close to the predicted region.

\section{DISCUSSION}

In this study, the horizontal expansion of Caulerpa taxifolia into unvegetated sediment was controlled by benthic light availability, water temperature and undetermined site- and season-specific factors, but negligibly affected by nutrient enrichment. This is between the annual cycles of benthic light dose and water temperature. Other site-specific factors such as grazing, epiphytic coverage and other factors were not measured in the experiments, but may have affected stolon extension rate.

Benthic light and water temperature accounted for $69 \%$ of the variation in the measured stolon extension (Eq. 4). Application of a general linear model based on the field measurements model (Eq. 5) enables these experimental measurements to be generalized and so provide insight into how key variables control horizontal expansion of Caulerpa taxifolia. For example, Eqs. (4) \& (5) indicate that the benthic light dose required for a critical stolon extension will be strongly affected by water temperature. This explains why shading did not reduce stolon extension in the Port River Estuary; under the warm, high light conditions of summer (Table 1), the C. taxifolia had enough light to expand even under $90 \%$ shading. In winter, C. taxifolia expansion was limited by the water temperature $\left(15^{\circ} \mathrm{C}\right)$; hence shading was not significant. In contrast, shading significantly reduced stolon extension in Pittwater, where temperature was 19 to $22^{\circ} \mathrm{C}$ during the experiments and 
light levels were moderate. In particular, our results suggest that $C$. taxifolia light requirements increase as temperature decreases, which is probably due to increasing photosynthesis rates with temperature up to an optimum temperature, beyond which photysnthesis declines (as shown by Blanchard \& Montagna 1992 for benthic microalgae). This result has broader implications as increases in water temperature (e.g. through thermal pollution or climate change) are likely to reduce $C$. taxifolia light requirements, and hence increase horizontal expansion rates in optically clear waters and the ability of C. taxifolia to spread into optically deep areas.

The validity of the statistical model developed here depends on the assumption that there are no changes in the correlative structure between explanatory variables (both those investigated and those not investigated), as per Scheffer \& Beets (1994). Hence the model may not be valid outside the temperature and light conditions under which it was developed, at other study sites, or even at these study sites under different biological or environmental conditions. For example, because maximum water temperature in this study was $29^{\circ} \mathrm{C}$, less than the temperature at which temperature begins to negatively affect photosynthesis in microalgae, negative effects of temperature on Caulerpa taxifolia were not captured in either the experimental results or the model. Uncertainty in values for $\bar{I}_{\text {daily }}$ due to the extrapolation of meteorological, water quality and tidal information measured over different timescales will also affect model performance. Despite these limitations, the model is a useful tool to interpolate the results within the range of light and temperature conditions captured in these experiments.

Lack of response to nutrient enrichment suggests that nutrients were not limiting Caulerpa taxifolia growth during any of our experiments. In Moreton Bay locations with large monotypic stands of C. taxifolia are typically in areas of degraded water quality with marginal seagrass communities (Thomas 2003, Burfeind \& Udy 2009). Furthermore, locations where C. taxifolia has been introduced are typically highly impacted areas (Chisholm et al. 1997, Fernex et al. 2001) already under environmental stress from a variety of factors including decreased water quality. Therefore, the poor environmental conditions that promote the loss of seagrass generate available space that is suitable for C. taxifolia to colonize, despite the high nutrient and low benthic light conditions (Burfeind \& Udy 2009). Additionally, thermal effluent from the Torrens Island Power Station substantially warmed the water in the Port River Estuary from $12^{\circ} \mathrm{C}$ (de Silva Samarasinghe et al. 2003) to $15^{\circ} \mathrm{C}$ during this study. C. taxifolia can survive, but not grow, in water temperatures between 10 and $12^{\circ} \mathrm{C}$ and does not grow until the water temperature is at least $15^{\circ} \mathrm{C}$ (Komatsu et al. 1997). Therefore, maintaining a water temperature at or above $15^{\circ} \mathrm{C}$ is likely to assist the persistence and spread of $C$. taxifolia in the Port River Estuary.

The results of the present study demonstrate the importance of measuring information across a wide range of environmental conditions, using quantitative variables which enable information measured across sites and seasons to be integrated in a single models. While site-specific ANOVAs indicated that shading only significantly affected the native population (Moreton Bay), the average daily light dose was found to be the most important predictor for total stolon extension when data were pooled across all sites. Overall, the effect of nutrient enrichment, benthic light and seasonal variation in water temperature on stolon extension rate were consistent between native (Moreton Bay) and invasive (Pittwater and Port River Estuary) locations.

This is the first study to have in situ measurements of Caulerpa taxifolia growth (stolon extension rate) in native $\left(20\right.$ to $\left.29^{\circ} \mathrm{C}\right)$ and invasive $\left(15\right.$ to $\left.26^{\circ} \mathrm{C}\right)$ locations. These experiments measured C. taxifolia growth across its full range of thermal tolerance as determined in laboratory studies (Komatsu et al. 1997, Chisholm et al. 2000). While there is high variability inherent in stolon extension measurement, our data indicate that native and invasive populations have a similar growth relationship with water temperature (Fig. 5).

Caulerpa taxifolia can grow across a broad range of light and nutrient climates, from clear oligotrophic reef systems (Phillips \& Price 2002) to very turbid and highly nutrient-enriched coastal environments (e.g. Port River Estuary, south-western Moreton Bay). Given this wide range of environmental tolerance, it is likely that once C. taxifolia is established within a system it will survive, with its ability to spread across unvegetated areas controlled primarily by the interaction between water temperature and benthic light availability and secondarily by other environmental factors (e.g. nutrient availability).

Acknowledgements. We acknowledge the many volunteers that assisted with this project in the laboratory and the field, particularly D. Gale, J. Street, A. Grinham, K. Moore, K. Ahern, M. Anzalone, J. Schofield, J. Testa, M. Whynne, R. Mari, C. Renck, C. Buckius, K. Zahmel, P. Maas and J. Nichols for their substantial field commitment 
to this project. We are grateful for logistical support and Caulerpa distribution data provided by the New South Wales Department of Primary Industries (NSW DPI) and South Australian Research and Development Institute (SARDI). E. T. White and A. Lulla assisted with data analysis and M. Arthur provided advice on mixed model approaches. Funding for this project was provided by the Department of Primary Industries and Resources of South Australia (PIRSA), Tangalooma Research Foundation UQ School of Engineering scholarship and a Moreton Bay Research Station Community scholarship. We are grateful for the comments from 3 anonymous referees on earlier drafts of this manuscript.

\section{LITERATURE CITED}

- Abal EG, Dennison WC (1996) Seagrass depth range and water quality in southern Moreton Bay, Queensland, Australia. Mar Freshw Res 47:763-771

Bell JD, Steffe AS, Westoby M (1988) Location of seagrass beds in estuaries: effects on associated fish and decapods. J Exp Mar Biol Ecol 122:127-146

Blanchard GF, Montagna PA (1992) Photosynthetic response of natural assemblages of marine benthic microalgae to short- and long-term variations of incident irradiance in Baffin Bay, Texas. J Phycol 28:7-14

$>$ Burfeind DD, Udy JW (2009) The effects of light and nutrients on Caulerpa taxifolia and seagrass interactions in Moreton Bay, Australia. Aquat Bot 90:105-109

> Ceccherelli G, Cinelli F (1997) Short-term effects of nutrient enrichment of the sediment and interactions between the seagrass Cymodocea nodosa and the introduced green alga Caulerpa taxifolia in a Mediterranean bay. J Exp Mar Biol Ecol 217:165-177

> Ceccherelli G, Sechi N (2002) Nutrient availability in the sediment and the reciprocal effects between the native seagrass Cymodocea nodosa and the introduced rhizophytic alga Caulerpa taxifolia. Hydrobiologia 474:57-66

Chapra SC (1997) Surface water-quality modelling. WCB McGraw-Hill, Boston, MA

Cheshire A, Westphalen G, Boxall V, March R and others (2002) Caulerpa taxifolia in West Lakes and in the Port River, South Australia: distribution, eradication options, and consequences. SARDI Aquatic Sciences, Adelaide

> Chisholm JRM, Dauga C, Ageron E, Grimont PAD, Jaubert JM (1996) 'Roots' in mixotrophic algae. Nature 381:382

> Chisholm JRM, Fernex FE, Mathieu D, Jaubert JM (1997) Wastewater discharge, seagrass decline and algal proliferation on the Cote d'Azur. Mar Pollut Bull 34:78-84

> Chisholm JRM, Marchioretti M, Jaubert JM (2000) Effect of low water temperature on metabolism and growth of a subtropical strain of Caulerpa taxifolia (Chlorophyta). Mar Ecol Prog Ser 201:189-198

Collings G, Westphalen G, Cheshire A, Rowling K, Theil M (2004) Caulerpa taxifolia (Vahl) C. Agardh eradication efforts in West Lakes, South Australia. Milestones Report to PIRSA Marine Habitat. SARDI Aquatic Sciences

Creese RG, Davis AR, Glasby TM (2004) Eradicating and preventing the spread of the invasive alga Caulerpa taxifolia in NSW. NSW Fisheries Final Report Series No. 64

> Day RW, Quinn GP (1989) Comparison of treatments after an analysis of variance in ecology. Ecol Monogr 59:433-463

$>$ de Silva Samarasinghe JR, Bode L, Mason LB (2003) Modelled response of Gulf St. Vincent (South Australia) to evaporation, heating and winds. Cont Shelf Res 23: 1285-1313

EHMP (Ecosystem Health Monitoring Program) (2006) Ecosystem Health Monitoring Program 2004-05 Annual Technical Report. Moreton Bay Waterways and Catchments Partnership, Brisbane

- Fabricius KE (2005) Effects of terrestrial runoff on the ecology of corals and coral reefs: review and synthesis. Mar Pollut Bull 50:125-146

> Fernex FE, Migon C, Chisholm JMR (2001) Entrapment of pollutants in Mediterranean sediments and biogeochemical indicators of their impact. Hydrobiologia 450:31-46

Grinham AR (2007) Downstream effects of land use on shallow-water benthic microalgal communities in Moreton Bay, Australia and Marovo Lagoon, Solomon Islands. PhD thesis, University of Queensland, Brisbane

> Hill D, Coquillard P, de Vaugelas J, Meinesz A (1998) An algorithmic model for invasive species: application to Caulerpa taxifolia (Vahl) C. Agardh development in the North-Western Mediterranean Sea. Ecol Modell 109: 251-265

Jones GK, Baker JL, Edyvane K, Wright GJ (1996) Nearshore fish community of the Port River-Barker Inlet Estuary. South Australia. I. Effect of thermal effluent on the fish community structure, and distribution and growth of economically important fish species. Mar Freshw Res 47:785-799

> Komatsu T, Meinesz A, Buckles D (1997) Temperature and light responses of alga Caulerpa taxifolia introduced into the Mediterranean Sea. Mar Ecol Prog Ser 146: $145-153$

> Komatsu T, Ishikawal T, Yamaguchi N, Hori Y, Ohba H (2003) But next time?: unsuccessful establishment of the Mediterranean strain of the green seaweed Caulerpa taxifolia in the Sea of Japan. Biol Invasions 5:275-277

Meinesz A, Hesse B (1991) Introduction of the tropical alga Caulerpa taxifolia and its invasion of the northwestern Mediterranean. Oceanol Acta 14:415-426

Meinesz A, Belsher T, Thibaut T, Antolic B and others (2001) The introduced green alga Caulerpa taxifolia continues to spread in the Mediterranean. Biol Invasions 3:201-210

> Occhipinti-Ambrogi A, Savini D (2003) Biological invasions as a component of global change in stressed marine ecosystems. Mar Pollut Bull 46:542-551

> Phillips JA, Price IR (2002) How different is Mediterranean Caulerpa taxifolia (Caulerpales: Chlorophyta) to other populations of the species? Mar Ecol Prog Ser 238:61-71

Poole HH, Atkins WRG (1929) Photo-electric measurements of submarine illumination throughout the year. J Mar Biol 16:297-324

Rabalais NN, Turner RE, Diaz RJ, Justic D (2009) Global change and eutrophication of coastal waters. ICES J Mar Sci 66:1528-1537

Ruesink JL, Collado-Vides L (2006) Modeling the increase and control of Caulerpa taxifolia, an invasive marine macroalga. Biol Invasions 8:309-325

Scheffer M, Beets J (1994) Ecological models and the pitfalls of causality. Hydrobiologia 275-276:115-124

Street J (2007) Environmental drivers of Caulerpa taxifolia growth and shifts in benthic infauna communities, Moreton Bay, Australia. Honours thesis, University of Queensland, Brisbane

Thibaut T, Meinesz A, Coquillard P (2004) Biomass seasonality of Caulerpa taxifolia in the Mediterranean Sea. Aquat Bot 80:291-297 
Thomas IM, Ainslie RC, Johnson DA, Ofller EW, Zed PA (1986) The effects of cooling water discharge on the intertidal fauna in the Port River Estuary, South Australia. Trans R Soc S Aust 110:159-172

Thomas J (2003) Caulerpa taxifolia in Moreton Bay — Distribution and seagrass interactions. Honours thesis. University of Queensland, Brisbane

Udy JW, Dennison WC (1997) Physiological responses of

Editorial responsibility: Just Cebrian,

Dauphin Island, Alabama, USA seagrasses used to identify anthropogenic nutrient inputs. Mar Freshw Res 48:605-614

- Williams SL (1984) Uptake of sediment ammonium and translocation in a marine green macroalga Caulerpa cupressoides. Limnol Oceanogr 29:374-379

Williams SL, Grosholz ED (2002) Preliminary reports from the Caulerpa taxifolia invasion in southern California. Mar Ecol Prog Ser 233:307-310

Submitted: February 17, 2011; Accepted: September 10, 2012 Proofs received from author(s): December 17, 2012 